\title{
Geometrical characteristics and hydraulic radius of packing devices
}

\author{
Aleksandr Pushnov \\ Department of Engineering Ecology, \\ Moscow State University of \\ Environmental Engineering (MSUEE), \\ Staraya Basmannaya, 21/4, \\ 105066 Moscow, Russia \\ E-mail:pushnovas@gmail.com
}

Generalization of data on geometrical characteristics of various types of bulk and regular packing of columned devices for realization of heat and mass transfer processes is presented.

Key words: nozzles of columned devices, specific surface, void fraction, hydraulic radius, equivalent diameter of the channel of a packing layer

\section{INTRODUCTION}

The parameters of heat and mass transfer processes in columned devices with a packing determine the basic geometrical characteristics defining the structure of the void fraction $e$ and a specific surface of a layer of a regular or bulk packing $a$ in the specified devices.

The size of the void fraction in a layer of the nozzle, numerically equal to the size of the alive section of a layer, defines the characteristic speed of a gas stream in a layer.

Below, under the basic geometrical characteristics of various bulk and regular packings for heat and mass transfer processes, results of the generalization of extensive data are presented with their interrelations with the hydraulic radius (equivalent diameter of the channel) of packed columned devices.

\section{EQUIVALENT DIAMETER OF THE CHANNEL OF PACKING DEVICES}

In the English literature, for the designation of the equivalent diameter of the channel, the term hydraulic radius is often used. Below, basically the term applied in Russia - equivalent diameter of the channel - is used.

In [1], it is offered to use the equivalent hydraulic diameter $d_{e}$ to define the geometrical size of channels of a complex section:

$$
d_{e}=4 \cdot F / P
$$

where $F$ is the cross-section area of the channel, $\mathrm{m}^{2}$ and $P$ are the moistened perimeter of the channel, $\mathrm{m}$.

Considering the current of a gas stream in a layer of a nozzle of Zhavoroncov and Aerov [2,3], the concept of equivalent diameter pore of the channel, equal to the quadruple hydraulic radius, is introduced:

$$
d_{e}=4 \cdot \varepsilon / a
$$

In [1], it is noted that the concept of equivalent diameter "generally is not universal and allows to count only losses of pressure in channels of various geometry by formulas for pipes of a round section".

On the other hand, analysis of the results of experiments undertaken in [4-8] on measuring the loss of pressure in granular layers of various geometrical form and size has shown that these results are generalized by the following equation [4]:

$$
E u_{m}=A+B / R e_{d e}
$$

In equation (3), $A=0.9, B=100$, and $E u_{m}$ is Euler's modified number:

$$
E u_{m}=\left(\Delta P \cdot \varepsilon^{2}\right) /\left(H \cdot a \cdot \rho \cdot W_{0}^{2}\right),
$$

where $\rho$ is the density of gas, $\mathrm{kg}-\mathrm{s}^{2} / \mathrm{m}^{4} ; H$ is the height of a layer of a packing, $\mathrm{m} ; \Delta P$ are losses of pressure, $\mathrm{kg} / \mathrm{m}^{2} ; W_{0}$ is the speed of gas, calculated for a full section of the empty de- 
vice, $\mathrm{m} / \mathrm{s} ; R e_{d e}$ is Reynolds' number reduced to the equivalent diameter of the channel in a layer of a nozzle:

$$
R e_{d e}=\left(W_{0} \cdot d_{e}\right) /(\varepsilon \cdot v)
$$

where $v$ is the kinematic viscosity of gas, $\mathrm{m}^{2} / \mathrm{s}$.

Thus, the use of the equivalent diameter of the channel $d$ e in equation (3) to define the geometrical parameter of a layer of a packing with reference to granular layers and connected to columned devices allows to calculate with a satisfactory accuracy losses of pressure in them. Hence, as regards packed columned devices, application of the equivalent diameter of the channel is quite justified for the hydraulic and other technological calculations of such devices.

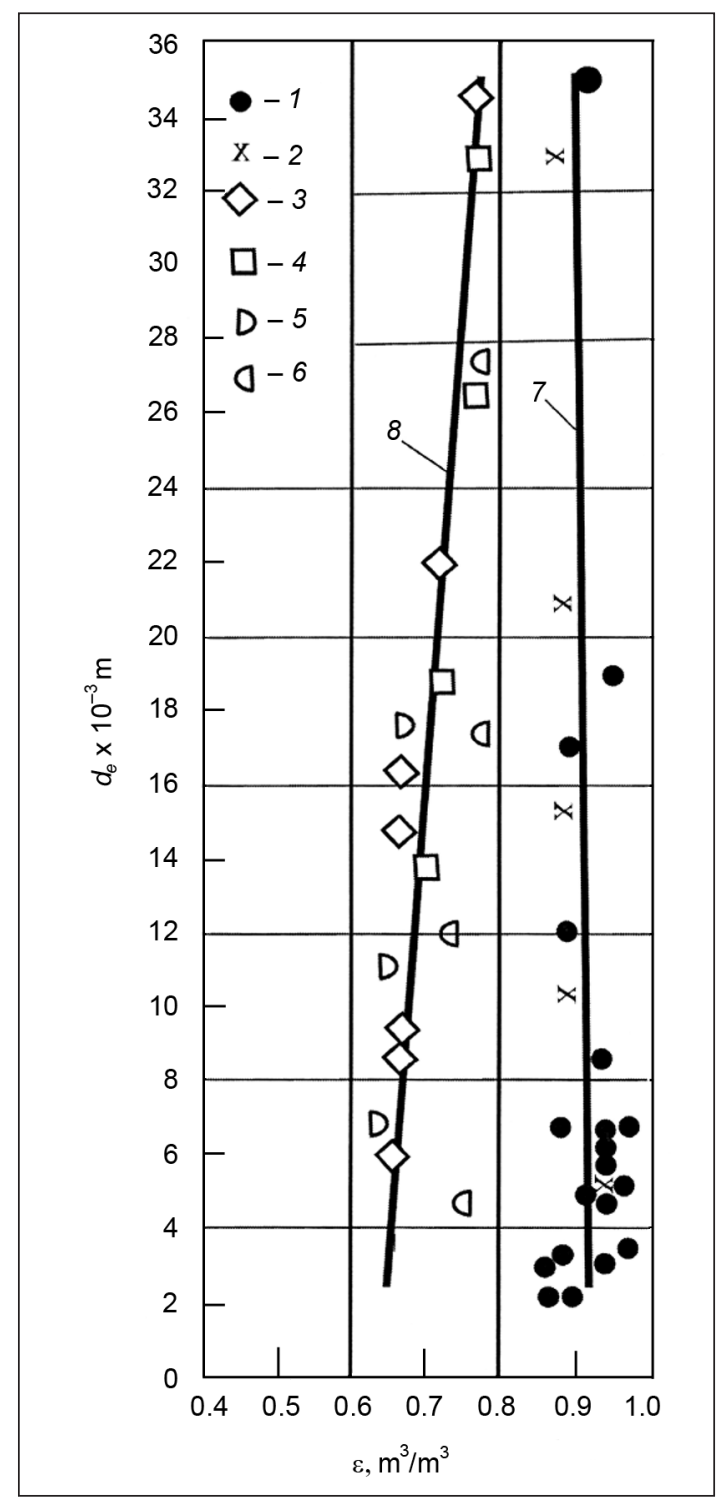

Fig. 1. Dependence $d_{e}=f(\varepsilon)$ for bulk metal and ceramic nozzles according to [9-15]

1 - Rashig steel rings; 2 - Pall steel rings; 3 - Rashig ceramic rings; 4 - Pall ceramic rings; 5 - Berl ceramic saddles; 6 - Intaloks ceramic saddles; 7 - our equation for metal bulk packings; 8 - our equation for ceramic bulk packings
DEPENDENCE OF THE VOID FRACTION AND A SPECIFIC SURFACE ON THE EQUIVALENT DIAMETER OF THE CHANNEL OF A LAYER OF A PACKING

The significant number of data on the geometrical characteristics of packings of various type and size allows to perform their generalization in the form of dependence of the void fraction $\varepsilon$ and a specific surface $a$ on such a major universal characteristic of a layer of a packing as the equivalent diameter of the channel $d_{e}$. Results of the generalization performed by us are presented in Figs. 1 and 2.

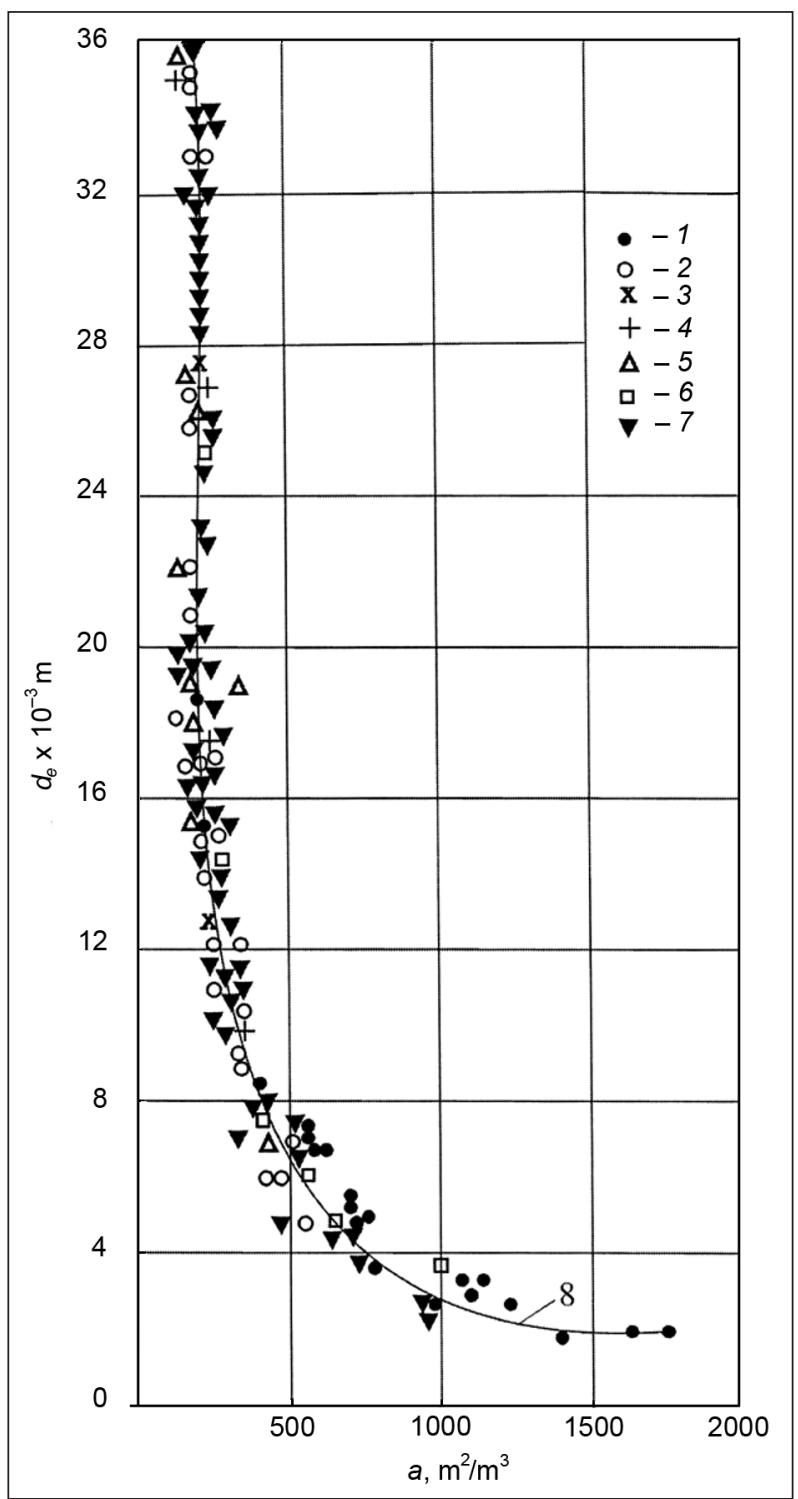

Fig. 2. Dependence of the size of equivalent diameter $d_{e}$ on the specific surface of bulk and regular packings $a$ :

1 - various bulk packings according to Polevoy [9]; 2 - bulk packings according to Vedernicov et al. [10]; 3 - bulk packings according to Kolev et al. [11]; 4 - Inzhkhim2000 bulk packings according to Laptev and Farahov [12]; 5 - regular packings according to $[10,13] ; 6$ - bulk packings according to [14]; 7 - bulk packings according to [15]; 8 - calculation based on our equation 
From dependence $d_{e}=f(\varepsilon)$, industrial bulk ceramic and metal packings in the form of a ring or saddle are described by two different curves (see Fig. 1). The curve for nozzles from thin-walled metal rings is located above in comparison with thick-walled ceramic packings, so that it is possible to explain the influence of wall thickness of a packings on the size of the void fraction. At the values of the equivalent diameter $d_{e}$ in the range $d_{e}=2 \cdot 10^{-3}-20 \cdot 10^{-3} \mathrm{~m}$, the void fraction of ceramic packings in all cases is by $19-20 \%$ lower in comparison with those of metal packings. At the values of $d_{e}$ more than $20 \cdot 10^{-3} \mathrm{~m}$, the difference in the values of the void fraction $\varepsilon$ for ceramic and metal packings decreases.

The effect of the equivalent diameter of a packing $d_{e}$ on the major geometrical parameter of a packing - specific surface $a$ - obtained by summarizing data of [9-15] is shown in Fig. 2. From two schemes presented in Fig. 2, a fivefold decrease in size of a specific surface from $1700 \mathrm{~m}^{2} / \mathrm{m}^{3}$ to $350 \mathrm{~m}^{2} / \mathrm{m}^{3}$ leads to an increase in the equivalent diameter of a packing from $d_{e}=2 \cdot 10^{-3} \mathrm{~m}$ up to $d_{e}=10^{-2} \mathrm{~m}$, i. e. also approximately fivefold.

The dependence $d=f(a)$ for packings of various form, made of ceramics and metal, appeared to be universal (see Fig. 2). Dependence $d_{e}=f(a)$ for all industrial packings with a deviation not exceeding $\pm 10 \%$ is described by the following equation:

$$
d_{e}=A \cdot a^{n}
$$

where $A=57319$, and $n=-1.3985$.

Equation (6), obtained as a result of summarizing numerous data presented in the literature, can be used for technological calculations of packed columned devices in chemical and other industries.

\section{CONCLUSIONS}

1. Dependence of the equivalent diameter of the channel of a packing layer on the specific surface of a packing layer of various type is established. The universal character of the dependence $d_{e}=f(a)$ for packings of any form and size with reference to packed ones is shown for columned devices. The equation allowing to estimate the size of the equivalent diameter of a packing for a preset value of its specific surface is offered.

2. A linear character of the dependence of the equivalent diameter of a packing on the void fraction in bulk ceramic and metal packings is established.

Received 22 February 2011 Accepted 28 April 2011

\section{References}

1. Subbotin V.I., Ibragimov M. Kh., Ushakov P. A., Bobkov V.P., Zhukov A. V., Yuryev Yu. Gidrodinamika i teploobmen v atomnykh energeticheskikh ustanovkakh (osnovy rascheta). Moskva: Atomizdat, 1975. 408 p.

2. Zhavoronkov N. M. Teoreticheskiye osnovy khimicheskoy tekhnologii. Moskva: Nauka, 2007. 351 p.

3. Aerov M. E., Todes O. M., Narinskiy D. A. Apparaty so statsionarnym zernistym sloem. Gidravlicheskiye i teplovyye osnovy raboty. Leningrad: Khimiya, 1979. 176 p.

4. Gelperin I. I., Kagan A. M., Krinitsyna G. I. Gidravlicheskoye soprotivleniye i udelnaya poverkhnost zernistykh materialov. Khimicheskaya promyshlennost. 1977. N 2. P. 67-68.

5. Gelperin I. I., Kagan A. M. Razvitiye aerodinamicheskikh issledovaniy nepodvizhnogo zernistogo sloya. Khimicheskaya promyshlennost. 1984. N 12. P. 37-42.

6. Pushnov A. S., Kagan A. M., Gelperin I. I. Gidravlicheskoye soprotivleniye chastits tsilindricheskoy i koltsevoy formy v perekhodnom rezhime techeniya. Poroshkovaya metallurgiya. 1982. N 3.P. 41-44.

7. Pushnov A. S. Gazoraspredeleniye v kontaktnykh i adsorbtsionnykh apparatakh s nepodvizhnym zernistym sloyem. Dis. ... kandidata tekhnicheskikh nauk. Moskva: GIAP, 1987. 353 p.

8. Pushnov A. S., Kagan A. M. Raschyot gidravlicheskogo soprotivleniya nepodvizhnnykh sloyov zyoren tsilindricheskoy formy razlichnogo razmera. Khimicheskaya promyshlennost. 1989. N 9. P. 54-57.

9. Polevoy A. S. Issledovaniye vysokoeffektivnykh nasadok pri rektifikatsii razbavlennykh rastvorov na osnove $\beta$-feniletilovogo spirta. Teoriticheskiye osnovy khimicheskoy tekhnologii. 1996. T. 30. N 5. P. 473-484.

10. Vedyornikova M. I., Startseva L. G., Yuryev Yu. L., Orlov V. G. Primery i zadachi po massoobmennym protsessam khimicheskoy tekhnologii. Ch. IV. Osnovnyye fizicheskiye, khimicheskiye $i$ teplofizicheskiye svoystva veshchestv. Yekaterinburg: Uralskiy gos. Lesotekhnicheskiy universitet, 2009. $154 \mathrm{p}$.

11. Kolev N., Vinkler K., Drakichen R., Brosh Z. Sozdaniye effektivnykh nasadok dlya kolonnykh apparatov na osnovye teorii massoobmennykh protsessov. Khimicheskaya promyshlennost. 1986. N 8. P. 489-493.

12. Laptyev A. G., Farakhov M. I. Razdeleniye geterogennykh sistem $v$ nasadochnykh apparatakh. Kazan: Kazanskiy gosudarstvennyy universitet, 2006. $342 \mathrm{p}$.

13. Dmitriyeva G. B., Berengartyen M. G., Klyushenkova M. I., Pushnov A. S. Effektivnyye konstruktsii strukturirovannykh nasadok dlya protsessov teplomassoobmena. Khimicheskoye i neftegazovoye mashinostroyeniye. 2005. N 8. P. 15-17.

14. Kast V., Krisher O., Raynike G., Vintyermantel K. Konvektivnyy teplo- $i$ massoperenos. Perevod s nemetskogo. Moskva: Energiya, 1980. 49 p.

15. Ganzinov I. Modeling of packed bed scrubber. Diplomityö TTKK. TUT, 2005. Tampere, Finland. 
Aleksandr Pušnov

İRENGINIŲ SU İKROVOMIS GEOMETRINĖS CHARAKTERISTIKOS

Santrauka

Pateikiamas esminis apibendrinimas pagrindinių duomenų, susijusių su ịvairių tipų ịkrovų koloniniuose įrenginiuose šilumos ir masès mainų procesais.

Raktažodžiai: įkrovos koloniniuose įrenginiuose, savitasis paviršius, hidraulinis spindulys (ekvivalentinis kanalo skersmuo)
Александр Пушнов

ГЕОМЕТРИЧЕСКИЕ ХАРАКТЕРИСТИКИ И ГИДРАВЛИЧЕСКИЙ РАДИУС В КОЛОННАХ С НАСАДКАМИ

Peзюме

Представляется обобщение основных данных, связанных с процессами тепло-массообмена в колонных аппаратах с насадками.

Ключевые слова: насадки в колонных аппаратах, удельная поверхность, гидравлический радиус, порозность (эквивалентный диаметр канала) 